\title{
A meta-analysis of leucine-rich repeat kinase 2 (LRRK2) polymorphisms in Alzheimer's disease
}

\author{
Reza Fatahian ${ }^{1}$, Seyed Reza Bagheri ${ }^{1}$, Masoud Sadeghi ${ }^{2,3}$ \\ ${ }^{1}$ Department of Neurosurgery, Kermanshah University of Medical Sciences, Kermanshah, ${ }^{2}$ Medical Biology Research Center, \\ Kermanshah University of Medical Sciences, Kermanshah, ${ }^{3}$ Students Research Committee, Kermanshah University of Medical \\ Sciences, Kermanshah, Iran
}

\begin{abstract}
Pathogenesis and the development of Alzheimer's disease $(A D)$ are subject to several environmental and genetic factors. This study was aimed to estimate the frequency of mutations in leucine-rich repeat kinase 2 (LRRK2) gene to examine the association between these mutations and risk of AD. For finding the articles, four databases including PubMed, Web of Science, Scopus, and Cochrane Library were checked up to August 2018. An analysis was done by RevMan 5.3 using crude odds ratio (OR) and 95\% confidence intervals (Cls) to determine the association between LRRK2 polymorphisms and the risk of $A D$. Of 359 articles identified in the databases, 13 studies were included and analysed in the meta-analysis. There was no significant risk of AD related to five LRRK2 polymorphisms (rs33949390, rs34778348, rs7308720, rs34637584, and rs35870237). The results showed that LRRK2 variants (p.R1628P, p.G2385R, p.N551K, p.G2019S, and p.I2020T) were not associated with the risk of $A D$ and were not a common cause of $A D$ in populations. Nevertheless, p.R1628P can be examined in patients with $A D$ in other populations in the future studies.
\end{abstract}

Key words: Alzheimer's disease, LRRK2, variants, polymorphism, meta-analysis.

\section{Introduction}

Alzheimer's disease (AD) is the leading neurodegenerative disease worldwide [12] and a common neurogenic disorder that mainly results in severe memory loss in the elderly ( $>60$ years) [14]. At present, there is no effective preventive treatment for $A D$ [12]. $A D$ is the most popular cause of dementia in the elderly and is considered a multifactorial disorder [19,21]. AD is largely sporadic although earlyonset familial $A D$ can represent up to $5 \%$ of the $A D$ cases assessed in memory clinics [3]. The pathogenesis and development of $A D$ include multiple envi- ronmental and genetic factors [14]. Leucine-rich repeat kinase 2 (LRRK2), also recognized as dardarin, depends on the Roco family of the Ras/GTPase super family [22]. Mutations of $L R R K 2$ are the most popular genetic reason for Parkinson's disease (PD) [22] and it has been assumed they are also central factors in the AD pathogenesis [20]. Two polymorphic variants of dardarin, including G2385R and R1628P, have previously been reported to have a relative risk of 1.9 of PD development in Chinese patients [4]. The purpose of this study was to calculate the frequency of mutations in the LRRK2 gene to investigate the association between the mutations and $A D$ risk.

\section{Communicating author}

Masoud Sadeghi, MSc, Medical Biology Research Center, Kermanshah University of Medical Sciences, Kermanshah, Iran, e-mail: sadeghi_mbrc@yahoo.com 


\section{Material and methods Strategy of search}

The Web of Science, PubMed, Scopus, and Cochrane Library databases were searched up to August 2018 using the search terms ("Alzheimer's disease" or "Alzheimer disease"; "LRRK2" or "Leucine-rich repeat kinase 2"; and polymorphism or variant* or gene or mutation*) without language restriction.

\section{Eligibility criteria}

One reviewer (M.S.) searched the articles and checked the titles, abstracts and then full texts of the studies to select the relevant studies based on the eligibility criteria. Another reviewer (R.F.) re-checked full texts. The inclusion criteria were the studies: 1) with case-control and cohort design; 2) including LRRK2 polymorphisms (p.G2385R, p.R1628P, p.N551K, p.G2019S, or p.I2020T); 3) reporting the patients with $A D$; 4) reporting allele or genotype distributions; and 5) including $A D$ diagnosis based on the protocols of NINCDS-ADRDA defined in the

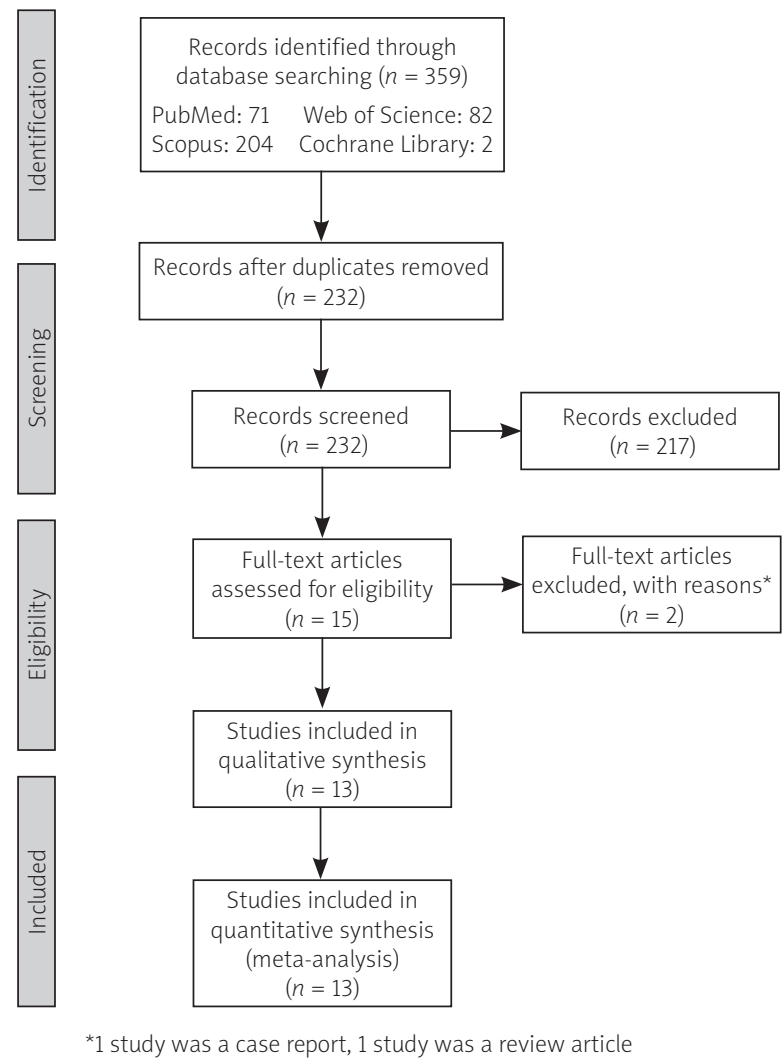

Fig. 1. Flow-chart of the study selection.
Tamaoka's study [16]. The exclusion criteria were: 1) animal studies; 2) reviews; and 3) case reports.

\section{Data extraction}

Two reviewers (M.S. and R.F.) independently took out the data, including the surname of the first author, location of participants, publication year, source of controls, allele and genotype distribution of NSCL/P and controls, and genotyping method.

\section{Statistical analysis}

An analysis was done by Review Manager 5.3 (RevMan 5.3, The Cochrane Collaboration, Oxford, United Kingdom) using crude odds ratio (OR) and 95\% confidence intervals ( $\mathrm{Cls}$ ) to determine the strength of association between LRRK2 polymorphisms and the risk of AD. The association was determined under the following five genetic models of the allelic, the homozygote, the heterozygote, the dominant, and the recessive. The significance of the pooled OR was evaluated when $p<0.05$. Heterogeneity across studies was evaluated using both Cochrane $\mathrm{Q}$ test and $\mathrm{I}^{2}$ statistic. There was statistically significant heterogeneity if $p<0.1$ or $\mathrm{I}^{2}>50 \%$. If no significant heterogeneity was found, the fixedeffect model was used to calculate the values. In any other way, the random-effect model was applied.

\section{Results}

A total of 359 articles were shown in the databases. After excluding the non-eligible articles, 13 studies were included and analysed in the meta-analysis (Fig. 1).

The information of the articles involved in the meta-analysis is shown in Table I. Four studies [8,10, 17,21] reported the patients/controls from Singapore, two studies [1,9] from China, and also Taiwan [2], England [11], Brazil [15], Norway [19], Italy [18], Europe/South America [5], and the USA [20], one study each. Four studies $[1,2,9,17]$ checked the distributions of rs34778348 polymorphism, three studies $[1,9,21]$ rs33949390 polymorphism, and two studies $[1,9]$ rs7308720 polymorphism in the patients with AD and the controls. Out of seven studies [1,5,8,15,18-20] reporting the distributions of rs34637584 polymorphism, just two studies [1,5] reported this polymorphism in the patients with AD and the controls. Out of two studies $[1,8]$ reporting rs35870237 polymorphism, just one study [1] reported this polymorphism in both groups. A total number of genotypes of each poly- 
Table I. Characteristics of the studies included in the meta-analysis

\begin{tabular}{|c|c|c|c|c|c|c|c|}
\hline The first author, year & $\begin{array}{l}\text { Location of } \\
\text { participants }\end{array}$ & $\begin{array}{l}\text { Source of } \\
\text { controls }\end{array}$ & $\begin{array}{l}\text { Genotype } \\
\text { method }\end{array}$ & $\begin{array}{l}\text { SNP } \\
\text { cDNA } \\
\text { Gene }\end{array}$ & Genotype & Case & Control \\
\hline Bi, 2014 [1] & China & $\mathrm{HB}$ & PCR-SBE & $\begin{array}{c}\text { Rs34778348 } \\
7153 G>A \\
\text { G2385R }\end{array}$ & GG/AG/AA & $1353 / 72 / 0$ & $1651 / 88 / 3$ \\
\hline Li, 2013 [9] & China & PB & PCR-RFLP & & & & \\
\hline Chang, 2010 [2] & Taiwan & PB & $\begin{array}{l}\text { PCR-MALDI- } \\
\text { TOF MS }\end{array}$ & & & & \\
\hline Tan, 2009 [17] & Singapore & $\mathrm{HB}$ & PCR & & & & \\
\hline $\mathrm{Bi}, 2014$ [1] & China & $\mathrm{HB}$ & PCR-SBE & $\begin{array}{c}\text { Rs33949390 } \\
4883 G>C \\
\text { R1628P }\end{array}$ & $\mathrm{GG} / \mathrm{CG} / \mathrm{CC}$ & $1203 / 42 / 0$ & $1966 / 61 / 20$ \\
\hline Li, 2013 [9] & China & PB & PCR-RFLP & & & & \\
\hline Zhao, 2011 [21] & Singapore & $\mathrm{HB}$ & PCR & & & & \\
\hline Patel, 2017 [11] & England & PB & PCR & $\begin{array}{c}\text { Rs7308720 } \\
1653 C>G \\
N 551 K\end{array}$ & $\mathrm{CC} / \mathrm{CG} / \mathrm{GG}$ & $667 / 132 / 4$ & $673 / 126 / 3$ \\
\hline Ng, 2017 [10] & Singapore & $\mathrm{HB}$ & PCR & & & & \\
\hline Toft, 2005 [19] & Norway & NCG & $\begin{array}{c}\text { PCR- } \\
\text { TaqMan }\end{array}$ & $\begin{array}{c}\text { Rs34637584 } \\
6055 G>A \\
\text { G2019S }\end{array}$ & GG/AG/AA & $2771 / 1 / 0$ & $3499 / 0 / 0$ \\
\hline $\begin{array}{l}\text { Santos-Rebouças, } 2009 \\
\text { [15] }\end{array}$ & Brazil & NCG & - & & & & \\
\hline Zabetian, 2006 [20] & USA & NCG & $\begin{array}{c}\text { PCR- } \\
\text { TaqMan }\end{array}$ & & & & \\
\hline $\mathrm{Bi}, 2014$ [1] & China & $\mathrm{HB}$ & PCR-SBE & & & & \\
\hline Tedde, 2007 [18] & Italy & NCG & PCR & & & & \\
\hline Lee, 2006 [8] & Singapore & NCG & PCR & & & & \\
\hline Hernandez, 2005 [5] & $\begin{array}{c}\text { Europe/South } \\
\text { America }\end{array}$ & PB & $\begin{array}{c}\text { PCR- } \\
\text { TaqMan }\end{array}$ & & & & \\
\hline Bi, 2014 [1] & China & $\mathrm{HB}$ & PCR-SBE & $\begin{array}{c}\text { Rs35870237 } \\
6059 \mathrm{~T}>\mathrm{C} \\
12020 \mathrm{~T}\end{array}$ & $\mathrm{TT} / \mathrm{CT} / \mathrm{CC}$ & $763 / 0 / 0$ & $819 / 0 / 0$ \\
\hline Lee, 2006 [8] & Singapore & NCG & PCR & & & & \\
\hline
\end{tabular}

SNP - single nucleotide polymorphism, PB - population-based, HB - hospital-based, NCG - no control group, MALDI-TOF-matrix-assisted laser desorption ionization time-of-flight mass spectrometry, $S B E$ - single-base extension, $P C R$ - polymerase chain reaction

morphism based on the included studies is shown in Table I. For two other polymorphisms (rs34637584 and rs35870237), we could not use the genetics models.

The risk of AD related to LRRK2 rs34778348, rs33949390, and rs7308720 polymorphisms based on five genetic models is shown in supplementary Figures 2-4, respectively. The pooled results have been summarized in Table II. There was no significant risk of AD related to three LRRK2 polymorphisms (rs34778348, rs33949390, and rs7308720). Also, based on Table I, there was no significant risk of $A D$ related to two other LRRK2 polymorphisms (rs34637584 and rs35870237).

\section{Discussion}

It is interesting to consider that the mutations of $L R R K 2$ have been linked with AD-like pathology [22] and also with the activation of programmed cell death signalling including the FADD/caspase- 8 metabolic pathways [6].

This meta-analysis evaluated the correlation of LRRK2 mutations with the AD risk. The results showed that rs34778348, rs33949390, rs7308720, rs34637584, and rs35870237 polymorphisms had no association with the risk of AD. Among the studies involved in the meta-analysis, two studies [1,21] 
Table II. The analysis of risk of Alzheimer's disease (AD) related to leucine-rich repeat kinase 2 (LRRK2) mutations

\begin{tabular}{|c|c|c|c|c|c|c|c|c|c|c|c|c|c|c|c|}
\hline \multirow[t]{2}{*}{ SNP ID } & \multicolumn{3}{|c|}{ A vs. G } & \multicolumn{3}{|c|}{ AA vs. GG } & \multicolumn{3}{|c|}{ AG vs. GG } & \multicolumn{3}{|c|}{$A A+A G$ vs. GG } & \multicolumn{3}{|c|}{$A A$ vs. $A G+G G$} \\
\hline & $\begin{array}{c}\text { OR } \\
(95 \% \mathrm{Cl})\end{array}$ & $1^{2}(\%)$ & $P_{h}$ & $\begin{array}{c}\text { OR } \\
(95 \% \mathrm{Cl})\end{array}$ & $\mathrm{I}^{2}(\%)$ & $P_{h}$ & $\begin{array}{c}\text { OR } \\
(95 \% \mathrm{Cl})\end{array}$ & $1^{2}(\%)$ & $P_{h}$ & $\begin{array}{c}\text { OR } \\
(95 \% \mathrm{Cl})\end{array}$ & $\mathrm{I}^{2}(\%)$ & $P_{h}$ & $\begin{array}{c}\text { OR } \\
(95 \% \mathrm{Cl})\end{array}$ & $R^{2}(\%)$ & $P_{h}$ \\
\hline \multirow[t]{3}{*}{ Rs34778348 } & $\begin{array}{c}0.94 \\
(0.69 \\
1.28) \\
\end{array}$ & 0 & 0.52 & $\begin{array}{c}0.18 \\
(0.01 \\
3.50) \\
\end{array}$ & - & - & $\begin{array}{c}1.00 \\
(0.73 \\
1.38) \\
\end{array}$ & 0 & 0.70 & $\begin{array}{c}0.97 \\
(0.71,1.33)\end{array}$ & 0 & 0.60 & $\begin{array}{c}0.18 \\
(0.01 \\
3.53) \\
\end{array}$ & - & - \\
\hline & \multicolumn{3}{|c|}{ C vs. G } & \multicolumn{3}{|c|}{ CC vs. GG } & \multicolumn{3}{|c|}{ CG vs. GG } & \multicolumn{3}{|c|}{ CC + CG vs. GG } & \multicolumn{3}{|c|}{ CC vs. $C G+G G$} \\
\hline & $\begin{array}{c}\text { OR } \\
(95 \% \mathrm{Cl})\end{array}$ & $\mathrm{I}^{2}(\%)$ & $P_{h}$ & $\begin{array}{c}\text { OR } \\
(95 \% \mathrm{Cl})\end{array}$ & $\mathrm{I}^{2}(\%)$ & $P_{h}$ & $\begin{array}{c}\text { OR } \\
(95 \% \mathrm{Cl})\end{array}$ & $1^{2}(\%)$ & $P_{h}$ & $\begin{array}{c}\text { OR } \\
(95 \% \mathrm{Cl}) \\
\end{array}$ & $\mathrm{I}^{2}(\%)$ & $P_{h}$ & $\begin{array}{c}\text { OR } \\
(95 \% \mathrm{Cl})\end{array}$ & $\mathrm{I}^{2}(\%)$ & $P_{h}$ \\
\hline \multirow[t]{3}{*}{ Rs33949390 } & $\begin{array}{l}1.07 \\
(0.41 \\
2.77) \\
\end{array}$ & 79 & 0.009 & - & - & - & $\begin{array}{l}1.07 \\
(0.41 \\
2.83) \\
\end{array}$ & 79 & 0.008 & $\begin{array}{l}1.07 \\
(0.41 \\
2.83) \\
\end{array}$ & 79 & 0.008 & - & - & - \\
\hline & \multicolumn{3}{|c|}{ G vs. C } & \multicolumn{3}{|c|}{ GG vs. CC } & \multicolumn{3}{|c|}{ CG vs. CC } & \multicolumn{3}{|c|}{ GG + CG vs. CC } & \multicolumn{3}{|c|}{ GG vs. CG + CC } \\
\hline & $\begin{array}{c}\text { OR } \\
(95 \% \mathrm{Cl})\end{array}$ & $1^{2}(\%)$ & $P_{h}$ & $\begin{array}{c}\text { OR } \\
(95 \% \mathrm{Cl})\end{array}$ & $\mathrm{I}^{2}(\%)$ & $P_{h}$ & $\begin{array}{c}\text { OR } \\
(95 \% \mathrm{Cl})\end{array}$ & $1^{2}(\%)$ & $P_{h}$ & $\begin{array}{c}\text { OR } \\
(95 \% \mathrm{Cl}) \\
\end{array}$ & $\mathrm{I}^{2}(\%)$ & $P_{h}$ & $\begin{array}{c}\text { OR } \\
(95 \% \mathrm{Cl})\end{array}$ & $\mathrm{I}^{2}(\%)$ & $P_{h}$ \\
\hline Rs7308720 & $\begin{array}{c}1.06 \\
(0.77 \\
1.47) \\
\end{array}$ & 9 & 0.3 & $\begin{array}{c}1.11 \\
(0.27 \\
4.66) \\
\end{array}$ & 0 & 0.92 & $\begin{array}{c}1.04 \\
(0.79 \\
1.36)\end{array}$ & 0 & 0.38 & $\begin{array}{c}1.04 \\
(0.80 \\
1.36) \\
\end{array}$ & 0 & 0.33 & $\begin{array}{c}1.10 \\
(0.26 \\
4.61)\end{array}$ & 0 & 0.94 \\
\hline
\end{tabular}

reported that p.R1628P (rs33949390) mutation was significantly linked with the risk of AD in Chinese and Singaporean individuals; whereas, another study [9] reported a significant protective role of this polymorphism in the Han Chinese population. With regard to other polymorphisms, no study showed a significant relationship between them and the risk of $A D$.

The p.G2019S mutation occurs at a frequency of around $1.3 \%$ in PD patients $(0.7 \%$ in sporadic and $3 \%$ in familial PD) and $0.06 \%$ in controls [7]. The frequency of this mutation in patients with PD changes from 0 in Chinese to $41 \%$ in North African Arabs populations across the world [13]. The variant of p.G2385R is an idea to be "East Asian"-specific, specifically in Han Chinese and Japanese populations [2]. Zhao et al. [21] showed that the p.R1628P increments the risk of $A D$ around two-fold in the Singaporean population. Lee et al. [8] reported that p.I2020T mutation was found to be a cause of autosomal dominant PD family in Japan, but the prevalence of p.G2019S might be different among ethnic races. The p.N551K is in connection disequilibrium with p.R1398H. It is possible that its protective action is controlled mainly by p.R1398H [10]. Four studies $[1,2,9,17]$ reporting p.G2385R (Rs34778348) mutation among 1425 patients with $A D$ and 1742 controls showed that the mutation occurred in 72 patients (4.2\%) and 91 controls (5.2\%). The p.R1628P (rs33949390) mutation in 1245 patients with AD and 2050 controls included 42 patients (3.4\%) and 81 controls (3.9\%) based on two studies included in the meta-analysis $[1,9,21]$. Two studies $[10,11]$ reported that the p.N551K (rs7308720) mutation occurred in $16.9 \%$ of patients with $A D$ and $16.1 \%$ of controls. Seven studies [1,5,8,15,18-20] included 2772 patients and 3499 controls and found that p.G2019S (rs34637584) mutation occurred in $0.36 \%$ of patients and none of controls. In addition, p.12020T (rs35870237) mutation was reported in none of the patients and controls. The studies were reported in few populations, which can be one of the most important limitations of this study.

\section{Conclusions}

This meta-analysis concluded that the $L R R K 2$ polymorphisms (p.G2385R, p.R1628P, p.N551K, p.G2019S, and p.I2020T) could not be associated with the risk of $A D$ and were not a common cause of $A D$ in populations. Nevertheless, p.R1628P can be examined in patients with $A D$ in other populations in future studies.

\section{Note}

The Figures 2-4 are included as a data supplement available with the online version of this article.

\section{Disclosure}

The authors report no conflict of interest. 


\section{References}

1. Bi R, Zhao L, Zhang C, Lu W, Feng JQ, Wang Y, Ni J, Zhang J, Li GD, Hu QX, Wang D, Yao YG, Li T. No association of the LRRK2 genetic variants with Alzheimer's disease in Han Chinese individuals. Neurobiol Aging 2014; 35: 444.e5-9.

2. Chang TY, Kuo HC, Lu CS, Wu-Chou YH, Huang CC. Analysis of the LRRK2 Gly2385Arg variant in Alzheimer's disease in Taiwan. Parkinsonism Relat Disord 2010; 16: 28-30.

3. Clarimón J, Djaldetti R, Lleó A, Guerreiro RJ, Molinuevo JL, Paisán-Ruiz C, Gómez-Isla T, Blesa R, Singleton A, Hardy J. Whole genome analysis in a consanguineous family with early onset Alzheimer's disease. Neurobiol Aging 2009; 30: 1986-1991.

4. Di Fonzo A, Wu-Chou YH, Lu CS, van Doeselaar M, Simons EJ, Rohé CF, Chang HC, Chen RS, Weng YH, Vanacore N, Breedveld GJ, Oostra BA, Bonifati V. A common missense variant in the LRRK2 gene, Gly2385Arg, associated with Parkinson's disease risk in Taiwan. Neurogenetics 2006; 7: 133-138.

5. Hernandez D, Paisan Ruiz C, Crawley A, Malkani R, Werner J, Gwinn-Hardy K, Dickson D, Wavrant Devrieze F, Hardy J, Singleton A. The dardarin G 2019 S mutation is a common cause of Parkinson's disease but not other neurodegenerative diseases. Neurosci Lett 2005; 389: 137-139.

6. Ho CC, Rideout HJ, Ribe E, Troy CM, Dauer WT. The Parkinson disease protein leucine-rich repeat kinase 2 transduces death signals via Fas-associated protein with death domain and caspase-8 in a cellular model of neurodegeneration. J Neurosci 2009; 29: 1011-1016.

7. Kay DM, Zabetian CP, Factor SA, Nutt JG, Samii A, Griffith A, Bird TD, Kramer P, Higgins DS, Payami H. Parkinson's disease and LRRK2: frequency of a common mutation in U.S. movement disorder clinics. Mov Disord 2006; 21: 519-523.

8. Lee E, Hui S, Ho G, Tan EK, Chen CP. LRRK2 G2019S and I2020T mutations are not common in Alzheimer's disease and vascular dementia. Am J Med Genet B Neuropsychiatr Genet 2006; 141B: 549-550.

9. Li HL, Lu SJ, Sun YM, Guo QH, Sadovnick AD, Wu ZY. The LRRK2 R1628P variant plays a protective role in Han Chinese population with Alzheimer's disease. CNS Neurosci Ther 2013; 19: 207-215.

10. Ng ASL, Ng EYL, Tan YJ, Kandiah N, Zhou J, Hameed S, Ting SKS, Tan EK. Case-control analysis of leucine-rich repeat kinase 2 protective variants in Alzheimer's disease. Neurobiol Aging 2018; 64: 157.e7-157.e9.

11. Patel T, Brookes KJ, Turton J, Chaudhury S, Guetta-Baranes T, Guerreiro R, Bras J, Hernandez D, Singleton A, Francis PT, Hardy J, Morgan K. Whole-exome sequencing of the BDR cohort: evidence to support the role of the PILRA gene in Alzheimer's disease. Neuropathol Appl Neurobiol 2017.

12. Pericak-Vance MA, Bass ML, Yamaoka LH, Gaskell PC, Scott WK, Terwedow HA, Menold MM, Conneally PM, Small GW, Saunders AM, Roses AD, Haines JL. Complete genomic screen in late-onset familial Alzheimer disease. Evidence for a new locus on chromosome 12. Neurobiol Aging 1998; 19: S39-42.

13. Punia S, Behari M, Govindappa ST, Swaminath PV, Jayaram S, Goyal V, Muthane UB, Juyal RC, Thelma BK. Absence/rarity of commonly reported LRRK2 mutations in Indian Parkinson's disease patients. Neurosci Lett 2006; 409: 83-88.
14. Querfurth HW, LaFerla FM. Alzheimer's disease. N Engl J Med 2010; 362: 329-344.

15. Santos-Rebouças CB, Abdalla CB, Martins PA, Baldi FJ, Santos JM, Motta LB, de Borges MB, Souza DR, de Souza Pinhel MA, Laks J, Pimentel MM. LRRK2 p.G2019S mutation is not common among Alzheimer's disease patients in Brazil. Dis Markers 2009; 27: 13-16.

16. Tamaoka A. Alzheimer's disease: definition and National Institute of Neurological and Communicative Disorders and Stroke and the Alzheimer's Disease and Related Disorders Association (NINCDS-ADRDA)]. Nihon Rinsho 2011; 69: 240-245.

17. Tan EK, Lee J, Chen CP, Wong MC, Zhao Y. Case control analysis of LRRK2 Gly2385Arg in Alzheimer's disease. Neurobiol Aging 2009; 30: 501-502.

18. Tedde A, Bagnoli S, Cellini E, Nacmias B, Piacentini S, Sorbi S. No association between the LRRK2 G2019S mutation and Alzheimer's disease in Italy. Cell Mol Neurobiol 2007; 27: 877-881.

19. Toft M, Sando SB, Melquist S, Ross OA, White LR, Aasly JO, Farrer MJ. LRRK2 mutations are not common in Alzheimer's disease. Mech Ageing Dev 2005; 126: 1201-1205.

20. Zabetian CP, Lauricella CJ, Tsuang DW, Leverenz JB, Schellenberg GD, Payami H. Analysis of the LRRK2 G2019S mutation in Alzheimer Disease. Arch Neurol 2006; 63: 156-157.

21. Zhao Y, Ho P, Yih Y, Chen C, Lee WL, Tan EK. LRRK2 variant associated with Alzheimer's disease. Neurobiol Aging 2011; 32: 19901993.

22. Zimprich A, Biskup S, Leitner P, Lichtner P, Farrer M, Lincoln S, Kachergus J, Hulihan M, Uitti RJ, Calne DB, Stoessl AJ, Pfeiffer RF, Patenge N, Carbajal IC, Vieregge P, Asmus F, Müller-Myhsok B, Dickson DW, Meitinger T, Strom TM, Wszolek ZK, Gasser T. Mutations in LRRK2 cause Autosomal-dominant parkinsonism with pleomorphic pathology. Neuron 2004; 44: 601-607. 